\title{
Influence of strength training and multicomponent training on the functionality of older adults: systematic review and meta-analysis
}

\section{Influência do treinamento de força e de multicomponentes na funcionalídade de idosos: revisão sistemática e metanálise}

Estele Caroline Welter Meereis Lemos ${ }^{1}$
(1) https://orcid.org/0000-0001-7827-1829
Eliane Celina Guadagnin ${ }^{2}$
(D) https://orcid.org/0000-0003-3250-4134
Carlos Bolli Mota ${ }^{3}$
(D) https://orcid.org/0000-0002-8025-0960

Abstract - Physical exercise is an important option to maintain functional independence in older adults, however, it is not clear which type of exercise is the most benefic: strength or multicomponent. The objective was to verify the effectiveness of strength training and multicomponent training on functionality of healthy older patients through a systematic review with meta-analysis. Registration number: CRD42017071887. Two independent evaluators searched Pubmed, Web of Science, PEDro, Cochrane and Lilacs databases. Of the 1434 studies found, 32 clinical trials that investigated the effects of strength training only and/or combined with other modalities (multicomponent) in older adults and evaluated the Timed up and Go (TUG), sit-to-stand (STS) and/or Berg Balance Scale (BBS) were included. The methodological quality was evaluated with the Downs \& Black scale. Data analysis was performed with the Software Review Manager. It was verified improvement in all the investigated outcomes when performing multicomponent training in comparison to control groups. Strength training, compared to control groups, showed benefit only for sit-to-stand test. Studies comparing the two trainings found no difference between them. The not high average score in the methodological quality assessment of the included studies is a limitation of the present study. In conclusion, both types of training were effective to improve functionality and are good strategies of training for older individuals. However, as the comparison between the two types of training was performed in few studies, it is not possible to infer which is more effective for the functionality, suggesting the realization of new clinical trials.

Key words: Aging; Exercise therapy; Meta-analysis; Resistance training.

Resumo - O exercício físico é uma opção importante para a manutenção da independência funcional nos idosos, porém, não está claro qual tipo de exercício pode ser mais benéfico. Diante disso, buscou-se verificar o efeito de intervençôes com treinamento de força e do treino com multicomponentes na funcionalidade em idosos saudáveis, através de uma revisão sistemática com metanálise. Número de registro: CRD42017071887. Foram realizadas buscas nas bases de dados Pubmed, Web of Science, PEDro, Cochrane e Lilacs. Dos 1434 estudos encontrados, 32 ensaios clinicos que realizaram treino de força elou combinado com outras modalidades (multicomponentes) em idosos e avaliaram os desfechos Timed up and Go (TUG), sentar-e-levantar (STS) elou Escala de Equilíbrio de Berg (EEB) foram incluidos. A qualidade metodológica foi avaliada pela escala Downs छ̋ Black. A análise dos dados foi realizada no Software Rewiew Manager. Verificou-se que os resultados favoreceram o treino multicomponentes em comparação aos grupos controle nos desfechos TUG, STS e EEB. Já para o treino de força isso ocorreu somente para o STS. Quando os dois treinamentos foram comparados, não houve favorecimento para nenhum deles. O escore médio não alto na avaliação da qualidade metodológica dos estudos incluidos é uma limitação do presente estudo. Conclui-se que ambos os treinos se mostraram efetivos para a funcionalidade e são boas estratégias de treinamento para idosos. Porém, como a comparação entre os dois tipos de treinamento foi realizada em poucos estudos, não é possivel afirmar qual é mais efetivo para a funcionalidade, sugerindo-se a realização de novos ensaios clínicos.

Palavras-chave: Envelhecimento; Terapia por exercício; Metanálise; Treinamento de resistência.
1 Universidade Federal do Rio de Janeiro. Rio de Janeiro, RJ. Brasil.

2 Universidade Federal do Pampa. Uruguaiana, RS. Brasil.

3 Universidade Federal de Santa Maria. Santa Maria, RS. Brasil.

Received: 16 December 2018 Accepted: 31 May 2019

How to cite this article Meereis-Lemos ECW, Guadagnin EC, Mota CB. Influence of strength training and multicomponent training on the functionality of older adults: systematic review and meta-analysis. Rev Bras Cineantropom Desempenho Hum 2020, 22:e60707. DOI: http://dx.doi.org/10.1590/19800037.2020v22e60707

Copyright: This work is licensed under a Creative Commons Attribution 4.0 International License. 


\section{INTRODUCTION}

Currently, the elder population is increasing at higher rates ${ }^{1}$. Throughout the aging process many changes occur in the neuromuscular, somatosensory, visual, vestibular systems, besides the body and bone compositions ${ }^{2}$. Additionally, the brain volume reduces at a rate of $5 \%$ per decade after the age of $40^{3}$. As a consequence, physical abilities decline, such as strength and balance, compromising basic and instrumental activities of daily life; besides, the mental health of older adults 2 .

The ability to maintain postural control is important for orthostatic position, ambulation, and for daily life activities. Postural imbalance in elderly subjects may indicate reduced ability to recover from small postural disorders, which may be a fall predictive factor ${ }^{4}$. It is important to detect the risks of falling in order to prevent them ${ }^{5}, \underline{6}$.

In order to assess the risks of falling, validated tests and scales are used, such as the Timed Up and Go (TUG), which is a quick and practical test to evaluate the physical mobility, gait speed and balance of individuals, and has already been described in the literature as a predictor of falls and an instrument for assessment of the dynamic balance ${ }^{7}$. Another widely used test is the Sit-to-Stand Test (STS), as a parameter to determine muscle strength, speed of performance of lower members strength and the functional ability to sit and stand up from the chair ${ }^{-}$. This test coul be performed in two ways: the number of repetitions performing during 30 seconds (30STS), or the time to performing 5 repetitions (5STS). Additionally, the Berg Balance Scale (BBS) is also used to evaluate the dynamic balance?

Physical exercise has been proved to be beneficial in the physical performance of older subjects, and is a strategy for the prevention of falls ${ }^{10}$, 11. Among several exercises modalities, strength training is a widely used method for the prevention of diseases associated with the development of co-morbidity and mortality in aging population, as well as improvement of physical performance through muscular strength. These exercises are based on the principle of overload, assuming that loads must be applied gradually, leading to an increased effort during the training sessions, aiming to provoke a disorder of cellular homeostasis and, in response, an adaptation to this stress. These adaptations occur at the muscular, neural and cellular levels ${ }^{12}$.

Strength exercises increase muscle mass in the elderly subjects of both genders, minimizing and even reversing sarcopenia. This process is characterized by low muscle strength, low muscle quantity or quality and low physical performance ${ }^{13}$. Strength exercises can also reduce the frequency of falls, thus contributing to the maintenance of independence and a better quality of life for the older individual $s^{14}$.

More recently, studies have shown that multicomponent exercises, which include an approach of different physical abilities may also be beneficial in maintaining and improving the functionality of the older population $\underline{15}-\underline{17}$. Besides minimizing sarcopenia, they contribute to the 
maintenance of balance, cardio-respiratory performance, flexibility, and are therefore recommended by the ACSM to increase and maintain the functionality of the older subjects $\underline{18}$.

However, it is unclear which of the two types of training may be best for the functionality of the elderly population. In order to demonstrate the evidence found in the literature on the subject, the objective of the present study was to conduct a systematic review with meta-analysis of clinical trials that investigated the effectiveness of strength training or multicomponent training on the functionality in older subjects, performing comparisons with a control group and between the two types of training.

\section{METHODS}

\section{Protocol and registration}

This study was registered in the PROSPERO under the number CRD42017071887. The present review follows the PRISMA statement.

\section{Design}

This study consists of a systematic review with meta-analysis of randomized controlled trials. This review includes studies that analyzed the effect of a training involving strength and/or multicomponent exercises (strength training combined with other exercises) on functional capacity of older subjects, evaluated by the Timed up and Go (TUG), sit-to-stand (5STS and/or 30 STS), and Berg Balance Scale tests (BBS). The following comparisons were performed: strength training versus control group, multicomponent training versus control group (no exercise), and multicomponent training versus strengh training.

\section{Search Strategy}

Systematic searches were performed in Pubmed, Web of Science, PEDro, Cochrane and Lilacs databases. The results of the search performed in each database were exported for further analysis.

The Mesh and keywords used in the search were related to the subjects (older individuals), type of training (strength training) and evaluated outcomes (TUG, STS and BBS). The terms used were combined through the Boolean operators "AND" and "OR", and a complete search example, carried out in the Pubmed database, are presented in supplementary document 1.

\section{Eligibility Criteria}

To be included in the present review, the articles should have been randomized controlled trials and have been performed only with healthy older adults 60 years or over residing in the community or in asylum institutions. Studies carried out with hospitalized older people or with some pathology were not included. The training performed should be only of strength or strength combined with other exercise modalities (multicomponent), with 
a total duration of at least 8 weeks and a weekly frequency of at least two sessions supervised by professionals. Studies that performed concurrent training supplementation and studies that did not have a control group which did not perform any type of exercise were not included. Regarding the outcomes, articles that evaluated one or more of the following tests were included: TUG, BBS and 30-second sit-to-stand test (30STS) or five repetitions (5STS). Those which did not present sufficient data regarding the results to perform the meta-analysis or that made adaptations in the tests (eg, inclusion of a double task) were excluded. Articles written in English, Portuguese or Spanish, which were published since 2006 were considered.

\section{Studies selection}

After the search in each database and export of the results, the selection of potential studies for inclusion in the present systematic review was carried out by two independent reviewers (ECWM and ECG) by reading their titles and abstracts, excluding only those that clearly did not fill the eligibility criteria. Articles that were selected by at least one of the reviewers, remained for the next stage of analysis.

Then, duplicated articles (found in more than one database) were excluded and the full texts were searched for articles that remained in the list after the initial selection. Two independent reviewers applied the eligibility criteria therein, and discrepancies were resolved by consensus.

\section{Quality assessment and risk of bias}

The methodological quality and risk of bias within and across the studies included in the present review was assessed using a PEDro scale for the evaluation of randomized controlled trials ${ }^{19}$.

\section{Data extraction and analysis}

In order to characterize the studies included in the systematic review, a standard form was used to organize data related to authorship, year of publication, information about study participants, characteristics of the training performed and methodology for evaluating the outcomes.

To analyze the effects of the trainings performed, through metaanalysis, the results found in each study (number of participants before and after training, mean and standard deviation of each outcome before and after training and results found) were included in a standard form.

For studies where there were more training groups, consisting of other types of training, besides strength training, only the data of the groups that performed strength exercises were included in the review. When there were two types of strength training in the same study, only data from the group that performed the type of training that was closest to a conventional strength training were used. In addition, when more than one type of concurrent training was performed, data from the group that performed strength training before the other exercises were used.

In the quantitative analysis, since the outcomes analyzed were continu- 
ous, the values of the weighted mean difference were used for the analysis with a $95 \%$ confidence interval. Delta values were used in the meta-analysis (difference between the pre and post-mean of each outcome). The results of the meta-analysis are presented in the unit of the investigated outcomes.

A random effects model was used, and the heterogeneity was assessed through the Cochran $Q$ test $(\mathrm{p} \leq 0.05$, indicating the existence of heterogeneity) and the inconsistency test $\left(\mathrm{I}^{2}\right.$, low heterogeneity: $\mathrm{I}^{2} \leq 25 \%$; moderate: $26 \%<\mathrm{I}^{2} \leq 50 \%$; and high: $\left.\mathrm{I}^{2}>50 \%\right)$. When moderate or high heterogeneity between the studies were found, sensitivity analyzes were performed, considering gender, total training program duration, mean age, number of subjects and characteristics of the exercises. A meta-analysis was performed separately for each outcome and for each comparison (control versus strength training, control versus multicomponent training, and multicomponent training versus strength training), and a level of significance was considered as $\mathrm{p}<0.05$. The analyses were performed using the Review Manager software, version 5.3 (Cochrane Collaboration).

\section{RESULTS}

\section{Articles search and selection}

After searching the defined databases using the search strategy, 1434 articles were found. Of these, 453 articles were selected by reading titles and abstracts and the full text was analyzed. After exclusion of duplicated articles, the eligibility criteria were applied, and 28 articles were included in the present systematic review with meta-analysis (Figure 1).

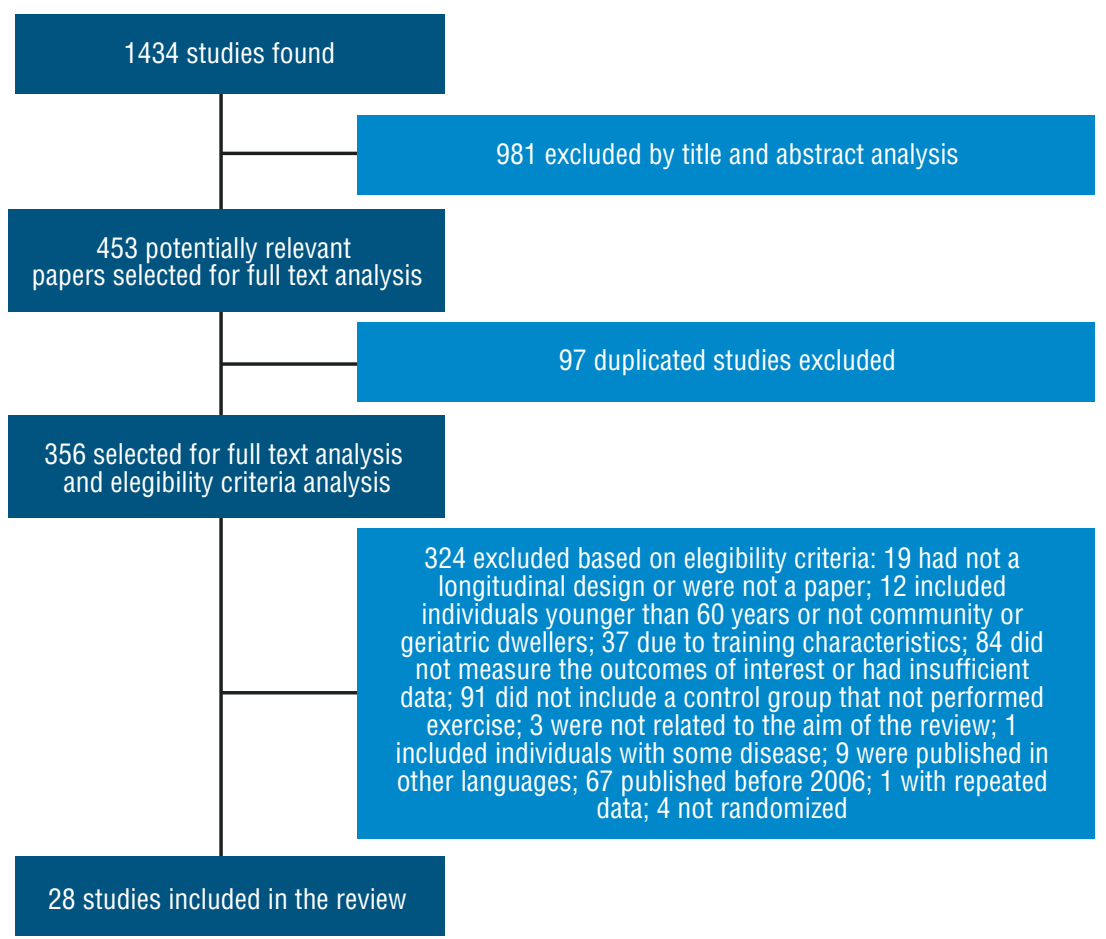

Figure 1. Flow diagram for search and selection of included articles 


\section{Quality Assessment}

The results of the methodological quality analysis of the studies included in the present review are presented in Supplementary document 2, individually for each study. The scale PEDro used allows a score of 0 to 11 points ${ }^{19}$. The overall mean of included studies was 6.93 points.

\section{Characteristics of included studies}

The main characteristics of the studies included in the present review regarding the participants and the details of the training performed are presented in Supplementary document 2.

\section{Effects of interventions}

The effect of the interventions performed was assessed by the meta-analysis. Comparisons were made between control group and strength training, between control group and multicomponent training (which included strength training and some training associated with it) and between multicomponent training and strength training. They are presented in Figures 2 to 5.

\section{Timed up \& go (TUG)}

In the comparison of the effect of multicomponent training group to control group, it was observed that the multicomponent training significantly improved $(\mathrm{p}<0.001)$ the TUG test performance, reducing the time needed to perform the test in -1.48 seconds ( $95 \% \mathrm{CI}-2.09 ;-0.88, \mathrm{I}^{2}=0 \%$ ) compared to the control group (Figure 2a).

When comparing the effect of the strength training groups to control groups, strength training did not improve significantly $(\mathrm{p}=0.14)$ the TUG performance [95\% confidence interval (CI) $-1.10,0.15, \mathrm{I}^{2}=63 \%$ ] (Figure 2b). Due to the fact that high heterogeneity occurred for this analysis, sensitivity analyses were performed. Through these analyses, it was not possible to identify which factor was related to the high heterogeneity, once that doing the analysis separately for studies that included only women or men or both, studies with different duration or different exercises did not reduce the heterogeneity.

None of the included studies compared the effect of a multicomponent workout with a strength training for this outcome.

\section{Sit-to-stand (30 seconds) - 30STS}

Comparing the effect of a multicomponent training with control group, it was verified that the multicomponent training significantly improved $(\mathrm{p}<0.001)$ the performance of the 30STS test, increasing the number of repetitions performed in 1.79 repetitions (IC 95\% 0.76, 2.83, $\mathrm{I}^{2}=52 \%$ ) (Figure 3a).

In a sensitivity analysis, it was observed that when studies that included a balance component in the training (in addition to aerobic and strength exercises which were performed in all studies), were withdrawn from the analysis, the heterogeneity changed from moderate (52\%) to low (0\%), 
while still maintaining the significant difference between the control group and the multicomponent group. However, the improvement without these studies was lower (0.89 repetitions), showing that studies which also included balance exercises in the training program presented better results.

a

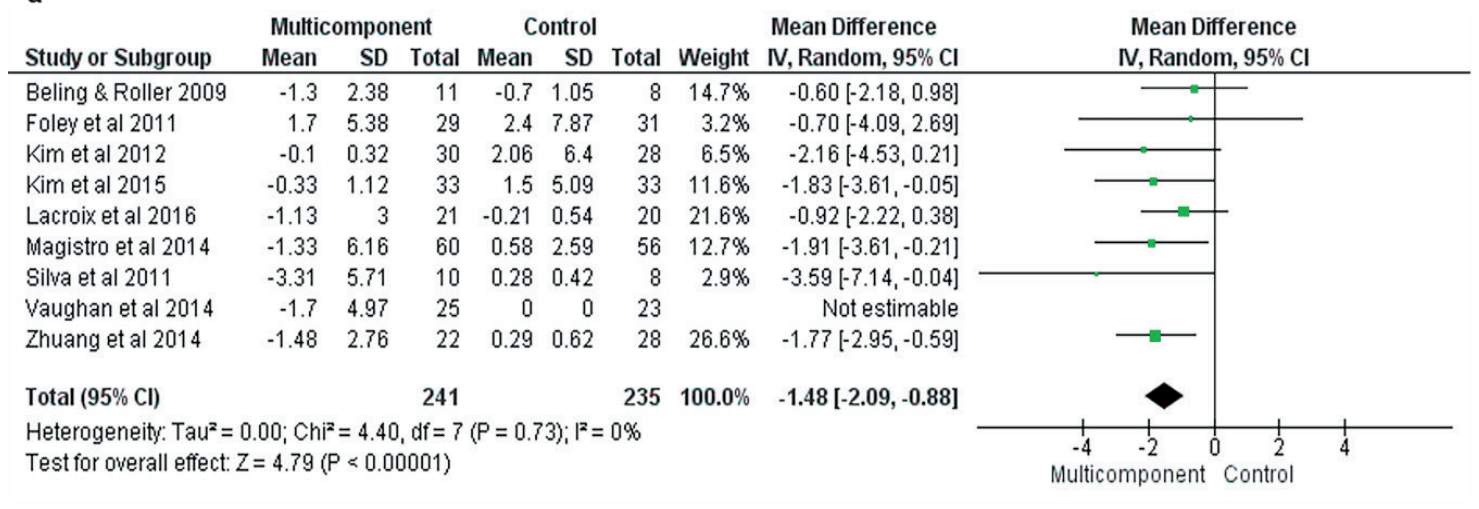

\begin{tabular}{|c|c|c|c|c|c|c|c|c|c|}
\hline \multirow{2}{*}{$\begin{array}{l}\text { b } \\
\text { Study or Subgroup }\end{array}$} & \multicolumn{3}{|c|}{ Strength } & \multicolumn{3}{|c|}{ Control } & \multicolumn{2}{|r|}{ Mean Difference } & \multirow{2}{*}{$\begin{array}{l}\text { Mean Difference } \\
\text { IV, Random, } 95 \% \mathrm{Cl}\end{array}$} \\
\hline & Mean & SD & Total & Mean & SD & Total & Weight & IV, Random, 95\% Cl & \\
\hline Granacher et al 2012 & -0.4 & 0.91 & 16 & 0.4 & 0.91 & 16 & $31.6 \%$ & $-0.80[-1.43,-0.17]$ & -1 \\
\hline Kalapotharakos et al 2010 & -2.27 & 3.09 & 7 & 0.38 & 0.52 & 7 & $6.3 \%$ & $-2.65[-4.97,-0.33]$ & \\
\hline Lustosa et al 2013 & -0.7 & 1.6 & 16 & -0.7 & 1.6 & 16 & $18.9 \%$ & $0.00[-1.11,1.11]$ & \\
\hline Raj et al 2012 & -0.21 & 0.41 & 12 & -0.08 & 0.16 & 13 & $43.3 \%$ & $-0.13[-0.38,0.12]$ & \\
\hline Total $(95 \% \mathrm{Cl})$ & & & 51 & & & 52 & $100.0 \%$ & $-0.48[-1.10,0.15]$ & \\
\hline \multicolumn{10}{|c|}{ 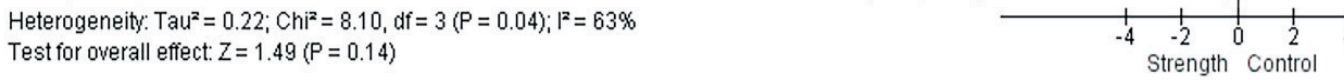 } \\
\hline
\end{tabular}

Figure 2. Analysis of Timed Up and Go comparing the multicomponent and control group (a), strength and control group (b). SD: standard deviation, $\mathrm{Cl}$ : confidence interval, I2: inconsistency test.

a

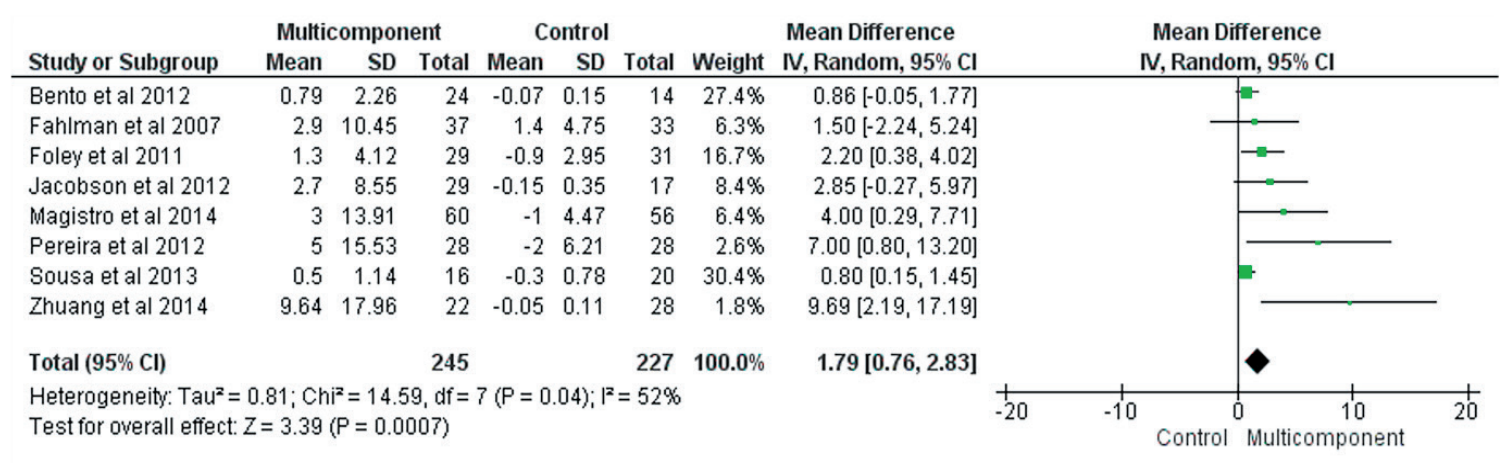

b

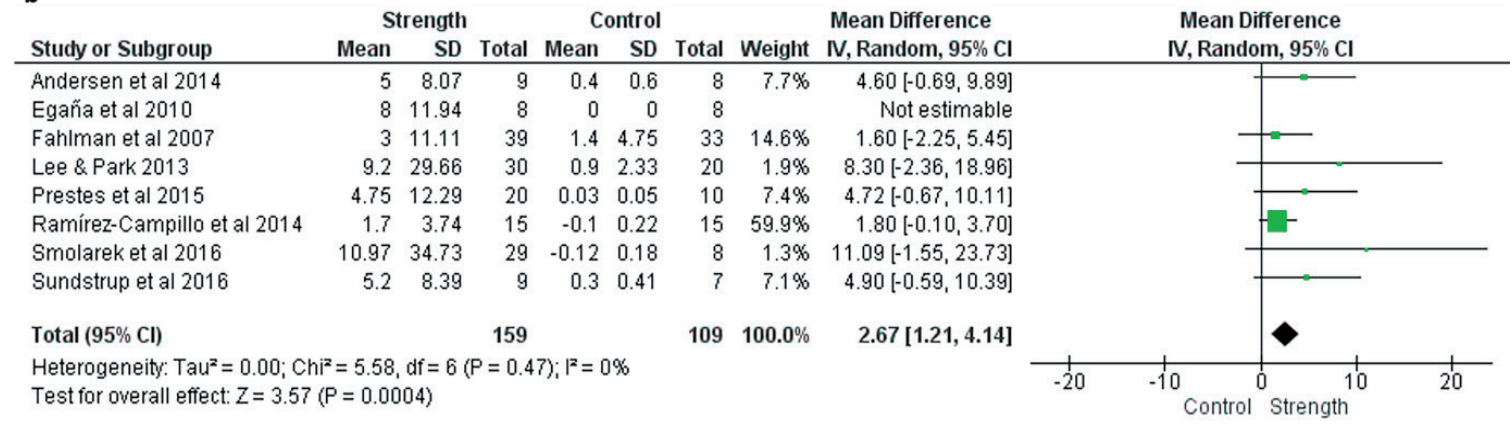

Figure 3. Analysis of sit-to-stand (30 seconds) - 30STS comparing the multicomponent and control group (a), strength and control group (b). SD: standard deviation, Cl: confidence interval, I2: inconsistency test.

Rev Bras Cineantropom Desempenho Hum 2020, 22:e60707 
a

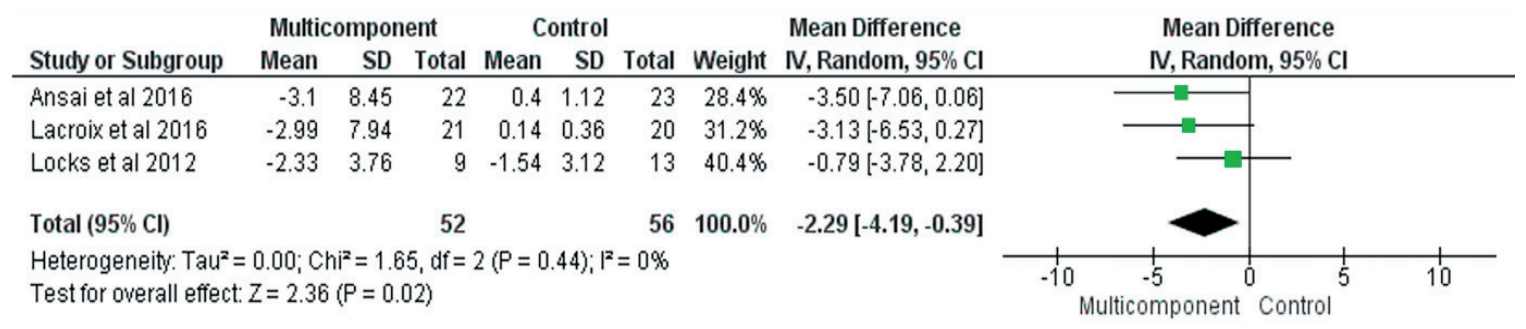

b

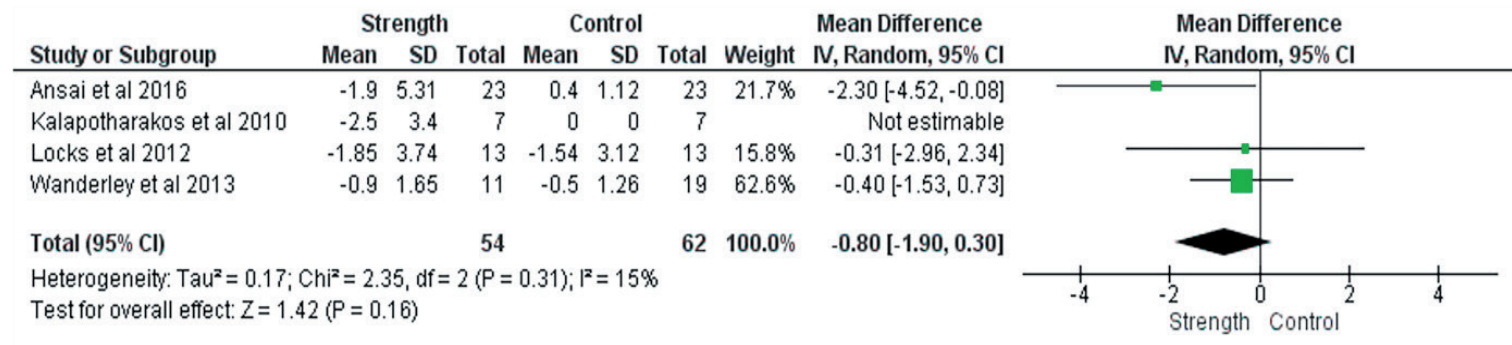

C

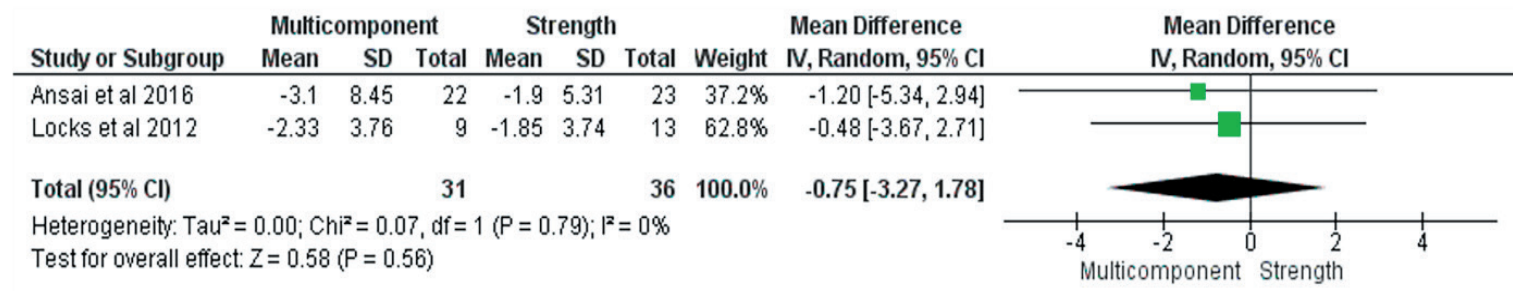

Figure 4. Analysis of sit-to-stand (5 repetitions) - 5STS comparing the multicomponent and control group (a), strength and control group (b) and multicomponent and strength group (c). SD: standard deviation, CI: confidence interval, I2: inconsistency test.

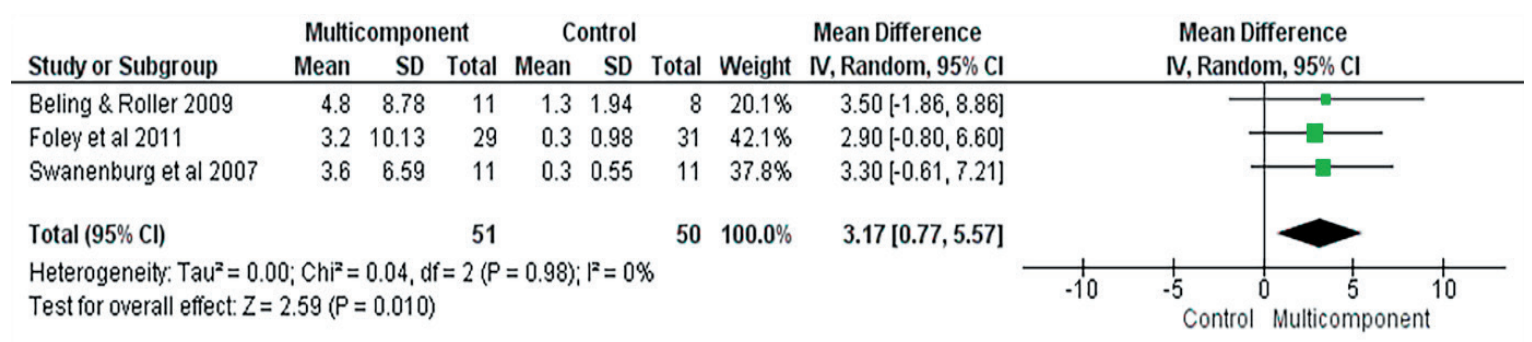

Figure 5. Analysis of Berg Balance Scale comparing the multicomponent and control group (a), strength and control group (b). SD: standard deviation, $\mathrm{Cl}$ : confidence interval, I2: inconsistency test.

Strength training compared to the control group significantly improved the performance of the 30STS test, increasing the number of repetitions performed in 2.51 repetitions (95\% CI 0.98; 4.03; $\mathrm{I}^{2}=0 \%$ ) (Figure 3b).

For the 30STS test only one study examined the effects of a strength training versus multicomponent workout. ${ }^{8}$ Therefore, no meta-analysis was performed. It can be observed from the change between pre and post training that the group that trained only strength increased 3.00 repetitions in the test and that who trained strength and other exercises increased 2.90 repetitions, on average, after the training, both groups had a very similar improvement. 


\section{Sit-to-stand (5 repetitions)- 5STS}

The multicomponent training group significantly improved the performance of the 5STS test, reducing the time to perform it in -2.29 seconds (95\% $\mathrm{CI}-4.19,-0.39, \mathrm{I}^{2}=0 \%$ ) when compared to the control group (Figure 4a).

Comparing strength training group to the control group, it was found that strength training did not improve significantly $(\mathrm{p}=0.16)$ the performance in the 5STS test (95\% CI -1.90, 0.30, $\mathrm{I}^{2}=15 \%$ ) (Figure $4 \mathrm{~b}$ ).

There was no difference $(\mathrm{p}=0.56)$ between the effects of strength training versus multicomponent training for the 5STS test (95\% CI -3.27, 1.78, $\left.\mathrm{I}^{2}=0 \%\right)($ Figure $4 \mathrm{c})$.

\section{Berg Balance Scale}

It was verified that multicomponent training group significantly increased the performance of the Berg Balance Scale by 3.17 points (95\% CI 0.77, $5.57, \mathrm{I}^{2}=0 \%$ ) compared to the control group (Figure 5).

None of the included studies compared the effect of a multicomponent workout with a strength training for this outcome, nor of a strength training group comparison to a control group.

\section{DISCUSSION}

The goal of this systematic review with meta-analysis was to investigate the effects of strength training and multicomponent training on the functionality and risk of falls in older subjects, evaluated by the TUG, STS and BBS tests. The results of the meta-analysis showed that the multicomponents training brought significant benefits to all the outcomes investigated, and that strength training only benefited performance in the 30-second sit-tostand test, when compared to control groups. Few studies compared the two types of training, and in those which made this comparison, no differences were found between them when considering the subjects' functionality.

In a descriptive analysis of the studies included in the present review, it was verified that most of the studies that evaluated the effect of multicomponent training or strength training on the functionality used the TUG test, since it was found in 13 of the 28 articles $9 \underline{21}, \underline{22}, \underline{25}, 26, \underline{33}-36, \underline{38}, \underline{40}, \underline{41}$, 43. The STS test was found in 19 studies, and 14 of them used the evaluation verifying the maximum number of repetitions that older subjects performed in 30 seconds of test (30STS) $1, \underline{8}, \underline{9}, \underline{20}, \underline{23}, \underline{27}, \underline{28}, \underline{30} \underline{32}, \underline{36}, \underline{37}, \underline{39}, \underline{41}$ and five studies used the assessment by checking the time the elders needed to perform the five times sit-to-stand task (5STS) 22, 24, 29, 호, $\underline{44}$. The Berg Balance Scale (BBS) was used in only three of the studies included in the review $^{9}, 42,43$. In addition, it was verified that most of studies used only one of the cited tests, and only 8 of them performed more than one of these functional tests $, \underline{22}, \underline{35}, \underline{36}, \underline{41}, 43$.

Regarding the results of the studies included in the meta-analysis, it was verified that the intervention performed with multicomponent training, the session being composed of strength, balance, aerobic and stretching 
exercises performed at least twice a week for a minimum duration of 8 weeks showed benefits to the healthy older adults in the four outcomes analyzed: TUG, 30STS, 5STS and BBS, when compared to the control group. This demonstrates that multicomponent training is a great strategy to improve functional capacity and decrease the risk of falls in older subjects.

These results are aligned to previous studies, where multicomponent training had positive effects on the functionality of older adults ${ }^{15-17}$. Similarly, the results of the meta-analysis with all the studies corroborate with the individual results of the studies, which have found significant improvements on the functionality $35, \underline{41}, \underline{43}, 44$.

On the other hand, strength training when performed as a single training modality demonstrated benefits in relation to the control group only in the 30STS test. For the other outcomes (TUG and 5STS) this type of training did not provide benefits. Additionally, regarding BBS, none of the studies investigated the effect of strength training on this parameter.

Other parameters that are related to the process of sarcopenia and the risk of falls, in addition to the functional performance evaluated in the present review, are the quantity of muscle mass and the strength, that can improve after both strength $\frac{26}{}$ and multicomponent $t^{15}$ training, and lead to positive effects on functional performance $\frac{13}{}$.

Few studies have compared strength training with multicomponent training. For the TUG outcome, the study by Fahlman et al. 8 found improvements in both types of training on this variable. For 30STS and BBS none of the included studies compared the effect of the two types of training. It was possible to perform meta-analysis only for the 5STS outcome, where there was no statistically significant difference in relation to the two types of training 24,44 . As only two studies could be included in this comparison, the results should be looked carefully.

In one of the studies of this comparison ${ }^{44}$, the authors applied strength training for one group and multicomponent training (strength, aerobic and balance exercises) to another for 16 weeks and verified that the group which participated of multicomponent training has significant improvement in 5STS, which did not occur for the strength training group. Based on this, the authors concluded that for older population, multicomponent training appears to be more beneficial and has fewer adverse events, as suggested by Gillespie et al. ${ }^{45}$ and recommendations from the ACSM 18 .

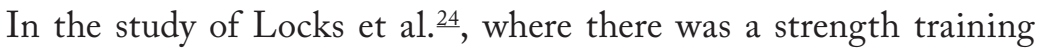
group and another one that performed strength exercises combined with stretching exercises, developed during 12 weeks, none of the groups had significant improvement after training in 5STS.

In addition, the evaluation of the methodological quality of the included studies showed that, on average, they scored 6.93 points. The scale used ${ }^{19}$ has a maximum score of 11 points. Thus, it is observed that the studies did not present high scores of methodological quality, which may influence the results found, being a limitation for the present study. 


\section{CONCLUSIONS}

Both strength and multicomponents exercises are good strategies to improve the functionality and decrease the risk of falls in older subjects, since both presented significant benefits when compared to the control group. However, multicomponent training demonstrated improvement in all outcomes analyzed in the present meta-analysis, while strength training showed benefit only for the 30STS outcome. As the comparison between the two types of training was performed in few studies, it is not possible to infer which is more effective for the functionality, suggesting the realization of new clinical trials.

\section{COMPLIANCE WITH ETHICAL STANDARDS}

\section{Funding}

This research did not receive any specific grant from funding agencies in the public, commercial, or not-for-profit sectors. This study was funded by the authors.

\section{Ethical approval}

Ethical approval was obtained from the local Human Research Ethics Committee -Federal University of Santa Maria and the protocol (no. 55992216.1.0000.5346) was written in accordance with the standards set by the Declaration of Helsinki.

\section{Conflict of interest statement}

The authors have no conflict of interests to declare.

\section{Author Contributions}

Conceived and designed the study: ECWML, ECG and CBM. Performed the data extraction: ECWML and ECG. Analyzed the data: ECG and ECWML. Wrote the paper: ECWML, ECG and CBM.

\section{REFERENCES}

1. Sundstrup E, Jakobsen MD, Andersen LL, Andersen TR, Randers MB, Helge JW, et al. Positive effects of 1-year football and strength training on mechanical muscle function and functional capacity in elderly men. Eur J Appl Physiol 2016;116(6):1127-38.

2. Youssef EF, Shanb AA. Supervised versus Home Exercise Training Programs on Functional Balance in Older Subjects. Malays J Med Sci 2016;23(6):83-93.

3. Peters R. Ageing and the brain. Postgrad Med J 2006;82(964):84-8.

4. Howcroft J, Lemaire ED, Kofman J, McIlroy WE. Elderly fall risk prediction using static posturography. PLoS One 2017;12(2):e0172398.

5. Arkkukangas M, Sundler AJ, Söderlund A, Eriksson S, Johansson AC. Older persons' experiences of a home-based exercise program with behavioral change support. Physiother Theory Pract 2017;33(12):905-913.

6. Singh DK, Pillai SG, Tan ST, Tai CC, Shahar S. Association between physiological falls risk and physical performance tests among community-dwelling older adults. Clin Interv Aging 2015;10:1319-26. 
7. Podsiadlo D, Richardson S. The timed "Up \& Go": a test of basic functional mobility for frail elderly persons. J Am Geriatr Soc 1991;39(2):142-8.

8. Fahlman M, Morgan A, McNevin N, Topp R, Boardley D. Combination training and resistance training as effective interventions to improve functioning in elders. J Aging Phys Act 2007;15(2):195-205.

9. Foley A, Hillier S, Barnard R. Effectiveness of once-weekly gym-based exercise programmes for older adults post discharge from day rehabilitation: a randomised controlled trial. Br J Sports Med 2011;45(12):978-86.

10. Fiogbé E, de Vassimon-Barroso V, Takahashi ACM. Exercise training in older adults, what effects on muscle oxygenation? A systematic review. Arch Gerontol Geriatr 2017;71:89-98.

11. Avin KG, Hanke TA, Kirk-Sanchez N, McDonough CM, Shubert TE, Hardage J, Hartley G, Association AOGPTOTAPT. Management of falls in communitydwelling older adults: clinical guidance statement from the Academy of Geriatric Physical Therapy of the American Physical Therapy Association. Phys Ther 2015;95(6):815-34.

12. Santiago LMA. Treinamento resistido reduz riscos cardiovasculares em idosas. Rev Bras Med Esporte 2015;21(4):261-265.

13. Cruz-Jentoft AJ, et al. Sarcopenia: revised European consensus on definition and diagnosis. Age Ageing 2019;48(1):16-31.

14. Prado RA, Egydio MRP, Teixeira CLA, Langa OSJC. A influência dos exercícios resistidos no equilíbrio, mobilidade funcional e na qualidade de vida de idosas. Mundo Saúde 2010; 34(2):183-191.

15. Cadore EL, Casas-Herrero A, Zambom-Ferraresi F, Idoate F, Millor N, Gómez M Rodriguez-Mañas L Izquierdo M. Multicomponent exercises including muscle power training enhance muscle mass, power output, and functional outcomes in institutionalized frail nonagenarians. Age (Dordr) 2014;36(2):773-85.

16. Mulasso A, Roppolo M, Liubicich ME, Settanni M, Rabagliett E. A Multicomponent Exercise Program for Older Adults Living in Residential Care Facilities: Direct and Indirect Effects on Physical Functioning. J Aging Phys Act 2015;23(3):409-16.

17. Bouaziz W, Lang PO, Schmitt E, Kaltenbach G, Geny B, Vogel T. Health benefits of multicomponent training programmes in seniors: a systematic review. Int $\mathrm{J}$ Clin Pract 2016;70(7):520-36.

18. Chodzko-Zajko WJ, Proctor DN, Fiatarone Singh MA, Minson CT, Nigg CR, Salem GJ, Skinner JS, Medicine ACOS. American College of Sports Medicine position stand. Exercise and physical activity for older adults. Med Sci Sports Exerc 2009;41(7):1510-30.

19. PEDro scale. The University of Sidney. Available from: https://www.pedro.org. au/english/downloads/pedro-scale [2017 July 30].

20. Egaña M, Reilly H, Green S. Effect of elastic-band-based resistance training on leg blood flow in elderly women. Appl Physiol Nutr Metab 2010;35(6):763-72.

21. Granacher U, Lacroix A, Muehlbauer T, Roettger K, Gollhofer A. Effects of core instability strength training on trunk muscle strength, spinal mobility, dynamic balance and functional mobility in older adults. Gerontology 2013;59(2):105-13.

22. Kalapotharakos VI, Diamantopoulos K, Tokmakidis SP. Effects of resistance training and detraining on muscle strength and functional performance of older adults aged 80 to 88 years. Aging Clin Exp Res 2010;22(2):134-40.

23. Lee IH, Park SY. Balance improvement by strength training for the elderly. J Phys Ther Sci 2013;25(12):1591-3.

24. Locks RR, Costa TC, Koppe S, Yamaguti AM, Garcia MC, Gomes ARS. Effects of strength and flexibility training on functional performance of healthy older people. Rev Bras Fisioter 2012;16(3):184-190. 
25. Lustosa LP, Máximo Pereira LS, Coelho FM, Pereira DS, Silva JP, Parentoni AN, et al. Impact of an exercise program on muscular and functional performance and plasma levels of interleukin 6 and soluble receptor tumor necrosis factor in prefrail community-dwelling older women: a randomized controlled trial. Arch Phys Med Rehabil 2013;94(4):660-6.

26. Raj IS, Bird SR, Westfold BA, Shield AJ. Effects of eccentrically biased versus conventional weight training in older adults. Med Sci Sports Exerc 201244 (6) 1167-76.

27. Ramírez-Campillo R, Castillo A, Fuente CI, Campos-Jara C, Andrade DC, Álvarez C, et al. High-speed resistance training is more effective than low-speed resistance training to increase functional capacity and muscle performance in older women. Exp Gerontol 2014;58:51-7.

28. Smolarek AEC, Ferreira LH, Mascarenhas LP, McAnulty SR, Varela KD, Dangui $\mathrm{MC}$, et al. The effects of strength training on cognitive performance in elderly women. Clin Interv Aging 2016;11:749-54.

29. Canuto Wanderley FA, Oliveira NL, Marques E, Moreira P, Oliveira J, Carvalho J. Aerobic versus resistance training effects on health-related quality of life, body composition, and function of older adults. J Appl Gerontol 2015; 34(3):NP143-65.

30. Andersen TR, Schmidt JF, Nielsen JJ, Randers MB, Sundstrup E Jakobsen MD, et al. Effect of football or strength training on functional ability and physical performance in untrained old men. Scand J Med Sci Sports 2014;24 (Suppl 1):76-85.

31. Bento PCB, Pereira G, Ugrinowitsch C, Rodacki ALF. The effects of a water-based exercise program on strength and functionality of older adults. J Aging Phys Act 2012;20(4):469-83.

32. Jacobson BH, Smith D, Fronterhouse J, Kline C, Boolani A. Assessment of the benefit of powered exercises for muscular endurance and functional capacity in elderly participants. J Phys Act Health 2012;9(7):1030-5.

33. Kim H, Suzuki T, Saito K, Yoshida H, Kojima N, Kim M, et al. Effects of exercise and tea catechins on muscle mass, strength and walking ability in communitydwelling elderly Japanese sarcopenic women: a randomized controlled trial. Geriatr Gerontol Int 2013;13(2):458-65.

34. Kim H, Suzuki T, Kim M, Kojima N, Ota N, Shimotoyodome A, et al. Effects of exercise and milk fat globule membrane (MFGM) supplementation on body composition, physical function, and hematological parameters in communitydwelling frail Japanese women: a randomized double blind, placebo-controlled, follow-up trial. PLoS One 2015;10(2):e0116256.

35. Lacroix A, Kressig RW, Muehlbauer T, Gschwind YJ, Pfenninger B, Bruegger O, et al. Effects of a Supervised versus an Unsupervised Combined Balance and Strength Training Program on Balance and Muscle Power in Healthy Older Adults: A Randomized Controlled Trial. Gerontology 2016;62(3):275-88.

36. Magistro D, Liubicich ME, Candela F, Ciairano S. Effect of ecological walking training in sedentary elderly people: act on aging study. Gerontologist 2014;54(4):611-23.

37. Pereira A, Izquierdo M, Silva AJ, Costa AM, Bastos E, González-Badillo JJ, et al. Effects of high-speed power training on functional capacity and muscle performance in older women. Exp Gerontol 2012;47(3):250-5.

38. Silva AM, Silva RB, Guerra RA, Siqueira GR. Physical therapy in relation to gait and balance in elderly women. Rev bras promoç saúde (Impr.) 2011;24(3):207-213.

39. Sousa N, Mendes R, Abrantes C, Sampaio J, Oliveira J. A randomized 9-month study of blood pressure and body fat responses to aerobic training versus combined aerobic and resistance training in older men. Exp Gerontol 2013;48(8):727-33.

40. Vaughan S, Wallis M, Polit D, Steele M, Shum D, Morris N. The effects of multimodal exercise on cognitive and physical functioning and brain-derived neurotrophic factor in older women: a randomised controlled trial. Age Ageing 2014;43(5):623-9. 
41. Zhuang J, Huang L, Wu Y, Zhang Y. The effectiveness of a combined exercise intervention on physical fitness factors related to falls in community-dwelling older adults. Clin Interv Aging 20149 131-40.

42. Swanenburg J, Bruin ED, Stauffacher M, Mulder T, Uebelhart D. Effects of exercise and nutrition on postural balance and risk of falling in elderly people with decreased bone mineral density: randomized controlled trial pilot study. Clin Rehabil 2007;21(6)523-34.

43. Beling J, Roller M. Multifactorial intervention with balance training as a core component among fall-prone older adults. J Geriatr Phys Ther 2009;32(3):125-33.

44. Ansai JH, Aurichio TR, Gonçalves R, Rebelatto JR. Effects of two physical exercise protocols on physical performance related to falls in the oldest old: A randomized controlled trial. Geriatr Gerontol Int 201616 (4) 492-9.

45. Gillespie LD, Robertson MC, Gillespie WJ, Sherrington C, Gates S, Clemson LM, et al. Interventions for preventing falls in older people living in the community. Cochrane Database Syst Rev 2012(9) CD007146.

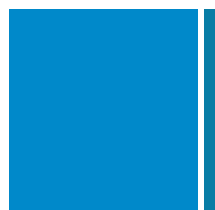

Corresponding author

Estele Caroline Welter Meereis Lemos

62 Ministro Viveiros de Castro street, appartment 808

Copacabana, Rio de Janeiro, RJ, Brazil

Zip code 22021-010

E-mail: estelefisio@gmail.com 


\section{SUPPLEMENTARY DOCUMENT 1}

\section{Search Strategy}

((aged OR elderly OR aged, 80 and over OR oldest old OR nonagenarians OR nonagenarian OR octogenarians OR octogenarian OR centenarians OR centenarian OR aging OR senescence OR biological aging OR aging, biological OR older OR ageing OR old) AND (resistance training OR Training, Resistance OR Strength Training OR Training, Strength OR Weight-Lifting Strengthening Program OR Strengthening Program, Weight-Lifting OR Strengthening Programs, Weight-Lifting OR Weight Lifting Strengthening Program OR Weight-Lifting Strengthening Programs OR Weight-Lifting Exercise Program OR Exercise Program, Weight-Lifting OR Exercise Programs, Weight-Lifting OR Weight Lifting Exercise Program OR Weight-Lifting Exercise Programs OR Weight-Bearing Strengthening Program OR Strengthening Program, Weight-Bearing OR Strengthening Programs, Weight-Bearing OR Weight Bearing Strengthening Program OR Weight-Bearing Strengthening Programs OR Weight-Bearing Exercise Program OR Exercise Program, Weight-Bearing OR Exercise Programs, Weight-Bearing OR Weight Bearing Exercise Program OR Weight-Bearing Exercise Programs) AND (timed up and go test OR timed up and go OR TUG or TUG test OR Berg balance OR Berg balance scale OR Berg OR Berg scale OR Berg balance test OR sit to stand OR sit to stand test OR 30 second sit to stand test OR 30 second sit to stand OR sit-to-stand OR sit-to-stand test OR five times sit-to-stand OR five times sit-to-stand test OR five-repetition sit-to-stand OR five-times-sit-to-stand OR five-times-sit-to-stand test)) 


\section{SUPPLEMENTARY DOCUMENT 2}

\section{Methodological quality assessment and characteristics of included articles}

\begin{tabular}{|c|c|c|c|c|c|c|c|c|c|c|c|}
\hline \multirow[b]{2}{*}{ 竞 } & \multicolumn{3}{|l|}{ Subjects } & \multicolumn{7}{|l|}{ Training } & \multirow[b]{2}{*}{$\begin{array}{l}\text { Pe- } \\
\text { Dro }\end{array}$} \\
\hline & Age & $\begin{array}{l}\text { Gender/ } \\
\text { Race }\end{array}$ & $\begin{array}{l}\text { Health condition/ } \\
\text { Medication }\end{array}$ & $\begin{array}{l}\text { Type of } \\
\text { training }\end{array}$ & $\begin{array}{l}\text { Performed } \\
\text { activities }\end{array}$ & $\begin{array}{l}\text { Weekly } \\
\text { frequency } \\
\text { (week) }\end{array}$ & $\begin{array}{l}\text { Session } \\
\text { duration } \\
\text { (min) }\end{array}$ & $\begin{array}{l}\text { Total } \\
\text { duration } \\
\text { (week) }\end{array}$ & Tests & Effect & \\
\hline 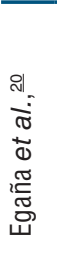 & $\begin{array}{l}\mathrm{E}: 69 \pm 5 \\
\mathrm{C}: 64 \pm 4\end{array}$ & $\begin{array}{l}\mathrm{E}: \mathrm{F} \\
\mathrm{C}: \mathrm{F} \\
\text { Race } \mathrm{NI}\end{array}$ & $\begin{array}{l}\text { Sedentary, nonsmok- } \\
\text { ers, normotensive no } \\
\text { apparent cardiovas- } \\
\text { cular disease/None } \\
\text { hormone replacement } \\
\text { therapy nether other } \\
\text { medication that could } \\
\text { affect cardiovascular }\end{array}$ & ST & $\begin{array}{l}\text { Warming } \\
\text { up, ST with } \\
\text { elastic bands } \\
\text { for lower } \\
\text { limbs, upper } \\
\text { limbs and } \\
\text { stretching }\end{array}$ & 3 & 60 & 12 & 30STS & $+p<0.05$ & 6 \\
\hline
\end{tabular}

\begin{tabular}{|c|c|c|c|c|c|c|c|c|c|c|c|}
\hline 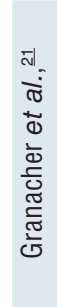 & $\begin{array}{l}\text { E: } 70.8 \pm \\
4.1 \\
\text { C: } 70.2 \pm \\
4.5\end{array}$ & $\begin{array}{l}\mathrm{E}: \mathrm{F} / \mathrm{M} \\
\mathrm{C}: \mathrm{F} / \mathrm{M} \\
\text { Race NI }\end{array}$ & $\begin{array}{l}\text { None had any history } \\
\text { of musculoskeletal, } \\
\text { neurological or or- } \\
\text { thopedic disorders, } \\
\text { all participants were } \\
\text { classified as non- } \\
\text { pathological in the } \\
\text { Clock Drawing Test } \\
\text { (CDT)/Medication NI }\end{array}$ & ST & ST for core & 2 & 60 & 9 & TUG & $+p<0.05$ & 7 \\
\hline 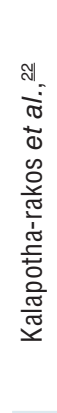 & $\begin{array}{l}\mathrm{E}: 83.4 \pm \\
2.8 \\
\mathrm{C}: 82.5 \\
\pm 2\end{array}$ & $\begin{array}{l}\mathrm{E}: \mathrm{M} \\
\mathrm{C}: \mathrm{M} \\
\text { Race NI }\end{array}$ & $\begin{array}{l}\text { Independent according } \\
\text { to the } \\
\text { functional ques- } \\
\text { tionnaire for BDL/ } \\
\text { IADL scale, without } \\
\text { cognitive impairment } \\
\text { or unstable cardiovas- } \\
\text { cular, metabolic, neu- } \\
\text { romuscular or other } \\
\text { chronic disease that } \\
\text { might limit training or } \\
\text { testing/Medication NI }\end{array}$ & ST & $\begin{array}{l}\text { ST for lower } \\
\text { limbs and } \\
\text { upper limbs }\end{array}$ & 2 & 60 & 14 & $\begin{array}{l}\text { TUG; } \\
\text { 5STS }\end{array}$ & $\begin{array}{l}\text { TUG: }+ \\
\text { p<0.001 } \\
\text { 5STS: } \\
\text { NS }\end{array}$ & 6 \\
\hline 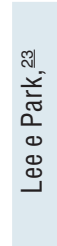 & $\begin{array}{l}\text { E: } 73.1 \pm \\
3.6 \\
\text { C: } 69.5 \pm \\
3.6\end{array}$ & $\begin{array}{l}\mathrm{E}: \mathrm{F} / \mathrm{M} \\
\mathrm{C}: \mathrm{F} / \mathrm{M} \\
\text { Race NI }\end{array}$ & $\begin{array}{l}\text { Normal cognition, no } \\
\text { cardiac or muscular } \\
\text { problems, no severe } \\
\text { cardiac disease or } \\
\text { orthopedic or neu- } \\
\text { rological disorders/ } \\
\text { Medication NI }\end{array}$ & ST & $\begin{array}{l}\text { ST for lower } \\
\text { limbs }\end{array}$ & $\mathrm{NI}$ & $\mathrm{NI}$ & 12 & 30STS & NS & 6 \\
\hline 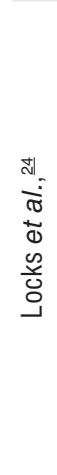 & $\begin{array}{l}\text { E: } 69.0 \pm \\
5.0 \\
\text { C: } 66.0 \pm \\
6.0\end{array}$ & $\begin{array}{l}\mathrm{E}: \mathrm{F} / \mathrm{M} \\
\mathrm{C}: \mathrm{F} / \mathrm{M} \\
\text { Race NI }\end{array}$ & $\begin{array}{l}\text { Stable condition, with- } \\
\text { out joint injury or sur- } \\
\text { gery, cardiac disease, } \\
\text { cancer, neuropathies, } \\
\text { no use of prostheses, } \\
\text { without contraindica- } \\
\text { tions for exercise in } \\
\text { accordance with the } \\
\text { Brazilian Hypertension } \\
\text { Guidelines or severe } \\
\text { functional limitations } \\
\text { as significant cognitive } \\
\text { impairment/Medica- } \\
\text { tion NI }\end{array}$ & ST & $\begin{array}{l}\text { ST for lower } \\
\text { limbs }\end{array}$ & 2 & \pm 55 & 24 & 5STS & NS & 6 \\
\hline
\end{tabular}

Continue... 
... continue

\begin{tabular}{|c|c|c|c|c|c|c|c|c|c|c|c|}
\hline \multirow[b]{2}{*}{ 辛 } & \multicolumn{3}{|l|}{ Subjects } & \multicolumn{7}{|l|}{ Training } & \multirow[b]{2}{*}{$\begin{array}{l}\text { Pe- } \\
\text { Dro }\end{array}$} \\
\hline & Age & $\begin{array}{l}\text { Gender/ } \\
\text { Race }\end{array}$ & $\begin{array}{l}\text { Health condition/ } \\
\text { Medication }\end{array}$ & $\begin{array}{l}\text { Type of } \\
\text { training }\end{array}$ & $\begin{array}{l}\text { Performed } \\
\text { activities }\end{array}$ & $\begin{array}{l}\text { Weekly } \\
\text { frequency } \\
\text { (week) }\end{array}$ & $\begin{array}{l}\text { Session } \\
\text { duration } \\
\text { (min) }\end{array}$ & $\begin{array}{l}\text { Total } \\
\text { duration } \\
\text { (week) }\end{array}$ & Tests & Effect & \\
\hline 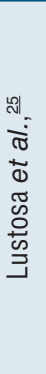 & $\begin{array}{l}E+C: \\
72.0 \pm 4.0\end{array}$ & $\begin{array}{l}\mathrm{E}: \mathrm{F} \\
\mathrm{C}: \mathrm{F} \\
\text { Race NI }\end{array}$ & $\begin{array}{l}\text { Prefrail older women } \\
\text { without cognitive im- } \\
\text { pairment, orthopedic } \\
\text { and neurologic diseas- } \\
\text { es that limited physical } \\
\text { activity, no acute } \\
\text { inflammatory disease } \\
\text { or cancer/without use } \\
\text { of medications with } \\
\text { known immunologic } \\
\text { effects. }\end{array}$ & ST & $\begin{array}{l}\text { Warming } \\
\text { up, strength } \\
\text { training for } \\
\text { lower limbs, } \\
\text { stretching e } \\
\text { relaxation }\end{array}$ & 3 & 60 & 10 & TUG & $+p<0.05$ & 8 \\
\hline 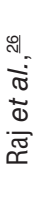 & $\begin{array}{l}E: 68 \pm 5 \\
C: 67 \pm 5\end{array}$ & $\begin{array}{l}\mathrm{E}: \mathrm{F} / \mathrm{M} \\
\mathrm{C}: \mathrm{F} / \mathrm{M} \\
\text { Race NI }\end{array}$ & $\begin{array}{l}\text { No relevant cardio- } \\
\text { vascular or orthopedic } \\
\text { problems/ Medica- } \\
\text { tion NI }\end{array}$ & ST & $\begin{array}{l}\text { Linear } \\
\text { strength } \\
\text { training for } \\
\text { lower limbs } \\
\text { and upper } \\
\text { limbs }\end{array}$ & 2 & $\mathrm{NI}$ & 16 & TUG & $+p<0.01$ & 6 \\
\hline 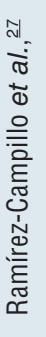 & $\begin{array}{l}E: 68.7 \pm \\
6.4 \\
C: 66.7 \pm \\
4.9\end{array}$ & $\begin{array}{l}\mathrm{E}: \mathrm{F} \\
\mathrm{C}: \mathrm{F} \\
\text { Race NI }\end{array}$ & $\begin{array}{l}\text { Healthy by self-report, } \\
\text { without heart disease, } \\
\text { osteoarthritis, severe } \\
\text { visual impairment, } \\
\text { neurological and } \\
\text { pulmonary disease, } \\
\text { uncontrolled hyperten- } \\
\text { sion, lower extremity } \\
\text { joint fracture/Medica- } \\
\text { tion NI }\end{array}$ & ST & $\begin{array}{l}\text { Warming } \\
\text { up, Strength } \\
\text { training for } \\
\text { lower limbs, } \\
\text { upper limbs } \\
\text { and core }\end{array}$ & 3 & \pm 70 & 12 & 30STS & $+p<0.05$ & 6 \\
\hline 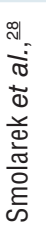 & $\mathrm{NI}$ & $\begin{array}{l}E: F \\
C: F\end{array}$ & $\begin{array}{l}\text { Patients that not exhib- } \\
\text { iting any Alzheimer's } \\
\text { symptoms or any other } \\
\text { neurodegenerative } \\
\text { disease previously } \\
\text { diagnosed by a doctor/ } \\
\text { Medication NI }\end{array}$ & ST & $\begin{array}{l}\text { ST for lower } \\
\text { limbs and } \\
\text { upper limbs }\end{array}$ & 3 & $\mathrm{NI}$ & 12 & 30STS & NS & 7 \\
\hline 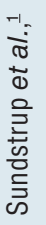 & $\begin{array}{l}E: 69.1 \pm \\
3.1 \\
\text { C: } 67.4 \pm \\
2.7\end{array}$ & $\begin{array}{l}\text { E: M } \\
\text { C: M } \\
\text { Race NI }\end{array}$ & $\begin{array}{l}\text { Healthy, nonsmok- } \\
\text { ers/No } \\
\text { Medication }\end{array}$ & ST & $\begin{array}{l}\text { ST for lower } \\
\text { limbs and } \\
\text { upper limbs }\end{array}$ & 3 & 70 & 48 & 30STS & $\begin{array}{l}+ \\
p=0.025\end{array}$ & 8 \\
\hline 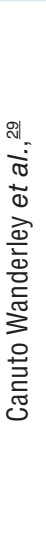 & $\begin{array}{l}E: 70.8 \pm \\
4.1 \\
C: 70.2 \pm \\
4.5\end{array}$ & $\begin{array}{l}\mathrm{E}: \mathrm{F} / \mathrm{M} \\
\mathrm{C}: \mathrm{F} / \mathrm{M} \\
\text { Race NI }\end{array}$ & $\begin{array}{l}\text { Without acute or } \\
\text { terminal illness, severe } \\
\text { or uncontrolled hy- } \\
\text { pertension, severe or } \\
\text { uncontrolled diabetes, } \\
\text { cardiovascular and/or } \\
\text { respiratory disorders, } \\
\text { any neurological, } \\
\text { skeletal-muscle, or } \\
\text { joint disorder or distur- } \\
\text { bance that precluded } \\
\text { participation in exer- } \\
\text { cise and testing/With- } \\
\text { out medication that } \\
\text { could reduce safety } \\
\text { during exercise }\end{array}$ & ST & $\begin{array}{l}\text { Warming } \\
\text { up, Strength } \\
\text { training for } \\
\text { lower limbs } \\
\text { and upper } \\
\text { limbs, relax- } \\
\text { ation }\end{array}$ & 3 & 50 & 32 & 5STS & $+p=0.03$ & 10 \\
\hline
\end{tabular}

Continue... 


\begin{tabular}{|c|c|c|c|c|c|c|c|c|c|c|c|}
\hline \multirow[b]{2}{*}{ 辛 } & \multicolumn{3}{|l|}{ Subjects } & \multicolumn{7}{|l|}{ Training } & \multirow[b]{2}{*}{$\begin{array}{l}\text { Pe- } \\
\text { Dro }\end{array}$} \\
\hline & Age & $\begin{array}{l}\text { Gender/ } \\
\text { Race }\end{array}$ & $\begin{array}{l}\text { Health condition/ } \\
\text { Medication }\end{array}$ & $\begin{array}{l}\text { Type of } \\
\text { training }\end{array}$ & $\begin{array}{l}\text { Performed } \\
\text { activities }\end{array}$ & $\begin{array}{l}\text { Weekly } \\
\text { frequency } \\
\text { (week) }\end{array}$ & $\begin{array}{l}\text { Session } \\
\text { duration } \\
\text { (min) }\end{array}$ & $\begin{array}{l}\text { Total } \\
\text { duration } \\
\text { (week) }\end{array}$ & Tests & Effect & \\
\hline 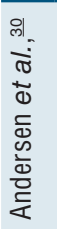 & $\begin{array}{l}\text { E: } 69.1 \pm \\
3.1 \\
\text { C: } 67.4 \pm \\
2.7\end{array}$ & $\begin{array}{l}\mathrm{E}: \mathrm{M} \\
\mathrm{C}: \mathrm{M} \\
\text { Race NI }\end{array}$ & $\begin{array}{l}\text { Healthy, nonsmok- } \\
\text { ers/No } \\
\text { medication }\end{array}$ & ST & $\begin{array}{l}\text { ST for lower } \\
\text { limbs, upper } \\
\text { limbs and } \\
\text { core }\end{array}$ & 2 & 60 & 16 & 30STS & $+p<0.01$ & 5 \\
\hline 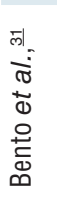 & $\begin{array}{l}\text { E: } 69.1 \pm \\
3.1 \\
\text { C: } 67.4 \pm \\
2.7\end{array}$ & $\begin{array}{l}\mathrm{E}: \mathrm{F} / \mathrm{M} \\
\mathrm{C}: \mathrm{F} / \mathrm{M} \\
\text { Race NI }\end{array}$ & Health/Medication NI & MT & $\begin{array}{l}\text { Water train- } \\
\text { ing: warming } \\
\text { up, aerobic } \\
\text { and strength } \\
\text { training and } \\
\text { stretching }\end{array}$ & 3 & 60 & 12 & 30STS & $+p=0.89$ & 5 \\
\hline $\begin{array}{l}\text { व } \\
\frac{\pi}{0} \\
\frac{0}{0} \\
\frac{d}{0} \\
\frac{1}{4}\end{array}$ & $\begin{array}{l}\text { E: } 78.3 \pm \\
6.5 \\
\text { C: } 79.9 \pm \\
8.4\end{array}$ & $\begin{array}{l}\mathrm{E}: \mathrm{F} / \mathrm{M} \\
\mathrm{C}: \mathrm{F} / \mathrm{M} \\
\text { Race: NI }\end{array}$ & $\begin{array}{l}\text { Cognitively intact, the } \\
\text { reason for referral } \\
\text { no involved spinal or } \\
\text { lower limb musculo- } \\
\text { skeletal impairment, } \\
\text { disability or surgery, } \\
\text { reduced functional } \\
\text { mobility or falls no } \\
\text { neurological disorder/ } \\
\text { Medication NI }\end{array}$ & MT & $\begin{array}{l}\text { Aerobic, } \\
\text { strength } \\
\text { and balance } \\
\text { training and } \\
\text { stretching }\end{array}$ & 2 & 60 & 12 & $\begin{array}{l}\text { TUG, } \\
\text { EBB, } \\
\text { 30STS }\end{array}$ & NS & 9 \\
\hline 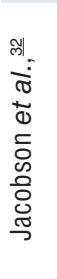 & $\begin{array}{l}\text { E: } \\
79.7 \pm 5.55 \\
\text { C: } \\
78.7 \pm 4.85\end{array}$ & $\begin{array}{l}\mathrm{E}: \mathrm{F} / \mathrm{M} \\
\mathrm{C}: \mathrm{F} / \mathrm{M} \\
\text { Race NI }\end{array}$ & Health/Medication NI & MT & $\begin{array}{l}\text { Strength } \\
\text { training with } \\
\text { motorized } \\
\text { exercise } \\
\text { apparatus for } \\
\text { lower limbs, } \\
\text { upper limbs } \\
\text { and core }\end{array}$ & 2 & 30 & 12 & 30STS & $\begin{array}{l}+ \\
p=0.006\end{array}$ & 6 \\
\hline 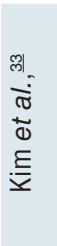 & $\begin{array}{l}\text { E: } 81.0 \pm \\
2.6 \\
\text { C: } 80.2 \pm \\
5.6\end{array}$ & $\begin{array}{l}E: F \\
C: F \\
\text { Race: } \\
\text { Japa- } \\
\text { nese }\end{array}$ & $\begin{array}{l}\text { Sarcopenic, no severe } \\
\text { knee or back pain; } \\
\text { no severely impaired } \\
\text { mobility and cognition; } \\
\text { stable cardiac condi- } \\
\text { tions/Medication NI }\end{array}$ & MT & $\begin{array}{l}\text { Stretching, } \\
\text { strength } \\
\text { training } \\
\text { with elastic } \\
\text { bands, bal- } \\
\text { ance and gait } \\
\text { training }\end{array}$ & 2 & 60 & 12 & TUG & $\begin{array}{l}+ \\
p<0.001\end{array}$ & 9 \\
\hline 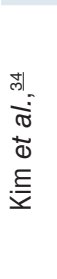 & $\begin{array}{l}\text { E: } 81.1 \pm \\
2.8 \\
\text { C: } 80.3 \pm \\
3.3\end{array}$ & $\begin{array}{l}E: F \\
C: F \\
\text { Race } \\
\text { Japa- } \\
\text { nese }\end{array}$ & $\begin{array}{l}\text { Frail women/Medica- } \\
\text { tion NI }\end{array}$ & MT & $\begin{array}{l}\text { Warming up, } \\
\text { stretching, } \\
\text { strength } \\
\text { training } \\
\text { with elastic } \\
\text { bands, bal- } \\
\text { ance and gait } \\
\text { training }\end{array}$ & 2 & 60 & 12 & TUG & $+p<0.01$ & 10 \\
\hline 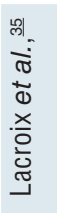 & $\begin{array}{l}\text { E: } 72.7 \pm \\
4.0 \\
\text { C: } 72.7 \pm \\
3.8\end{array}$ & $\begin{array}{l}\mathrm{E}: \mathrm{F} / \mathrm{M} \\
\mathrm{C}: \mathrm{F} / \mathrm{M} \\
\text { Race NI }\end{array}$ & $\begin{array}{l}\text { Health, all participants } \\
\text { were classified as } \\
\text { nonpathological on } \\
\text { CDT/Medication NI }\end{array}$ & MT & $\begin{array}{l}\text { Balance } \\
\text { training, } \\
\text { strength } \\
\text { training for } \\
\text { lower limbs } \\
\text { and core }\end{array}$ & 3 & 45 & 12 & $\begin{array}{l}\text { TUG; } \\
\text { 5STS }\end{array}$ & $+p<0.05$ & 6 \\
\hline
\end{tabular}

Continue... 
.. continue

\begin{tabular}{|c|c|c|c|c|c|c|c|c|c|c|c|}
\hline \multirow[b]{2}{*}{ 苇 } & \multicolumn{3}{|l|}{ Subjects } & \multicolumn{7}{|l|}{ Training } & \multirow[b]{2}{*}{$\begin{array}{l}\text { Pe- } \\
\text { Dro }\end{array}$} \\
\hline & Age & $\begin{array}{l}\text { Gender/ } \\
\text { Race }\end{array}$ & $\begin{array}{l}\text { Health condition/ } \\
\text { Medication }\end{array}$ & $\begin{array}{l}\text { Type of } \\
\text { training }\end{array}$ & $\begin{array}{l}\text { Performed } \\
\text { activities }\end{array}$ & $\begin{array}{l}\text { Weekly } \\
\text { frequency } \\
\text { (week) }\end{array}$ & $\begin{array}{l}\text { Session } \\
\text { duration } \\
\text { (min) }\end{array}$ & $\begin{array}{l}\text { Total } \\
\text { duration } \\
\text { (week) }\end{array}$ & Tests & Effect & \\
\hline 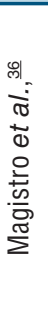 & $\begin{array}{l}\mathrm{E}: 72 \pm \\
4.5 \\
\mathrm{C}: 74.1 \pm \\
6.0\end{array}$ & $\begin{array}{l}\text { E: F/M } \\
\text { C: F/M } \\
\text { Race NI }\end{array}$ & $\begin{array}{l}\text { Health without myo- } \\
\text { cardial infarction and } \\
\text { or coronary bypass } \\
\text { surgery, uncontrolled } \\
\text { diabetes or hyper- } \\
\text { tension, orthopedic } \\
\text { impairment, or upper } \\
\text { or lower extremity } \\
\text { fracture/Medication NI }\end{array}$ & MT & $\begin{array}{l}\text { Strength } \\
\text { training for } \\
\text { lower limbs, } \\
\text { balance and } \\
\text { gait training }\end{array}$ & 2 & 75 & 16 & $\begin{array}{l}\text { TUG; } \\
\text { 30STS }\end{array}$ & $\begin{array}{l}+ \\
p<0.0001\end{array}$ & 6 \\
\hline 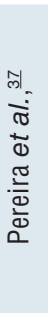 & $\begin{array}{l}E: 62.5 \pm \\
5.4 \\
\text { C: } 62.2 \pm \\
4.3\end{array}$ & $\begin{array}{l}E: F \\
C: F \\
\text { Race: } \\
\text { Cauca- } \\
\text { sian }\end{array}$ & $\begin{array}{l}\text { Health condition: NI/ } \\
\text { Medication: NI }\end{array}$ & MT & $\begin{array}{l}\text { Warming } \\
\text { up, strength } \\
\text { training } \\
\text { for lower } \\
\text { limbs and } \\
\text { upper limbs, } \\
\text { balance } \\
\text { training and } \\
\text { stretching }\end{array}$ & 3 & 60 & 12 & 30STS & $+p<0.05$ & 6 \\
\hline 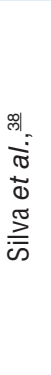 & $\begin{array}{l}\text { E: } 69.3 \pm \\
6.55 \\
\text { C: } 70.5 \pm \\
6.03\end{array}$ & $\begin{array}{l}\mathrm{E}: \mathrm{F} \\
\mathrm{C}: \mathrm{F} \\
\text { Race NI }\end{array}$ & $\begin{array}{l}\text { With low density } \\
\text { mineral bone or with } \\
\text { osteopenic or osteopo- } \\
\text { rosis, no impaired cog- } \\
\text { nition; musculoskel- } \\
\text { etal, and/or neurologic } \\
\text { without pain during the } \\
\text { walk/No medication } \\
\text { with corticosteroids, } \\
\text { anticonvulsants or } \\
\text { metotrexato }\end{array}$ & MT & $\begin{array}{l}\text { Strength } \\
\text { training, gait } \\
\text { and balance } \\
\text { training and } \\
\text { stretching }\end{array}$ & 3 & 60 & 10 & TUG & $\stackrel{+}{p=0.004}$ & 4 \\
\hline 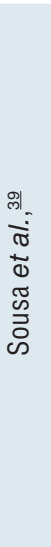 & $\mathrm{NI}$ & $\begin{array}{l}\mathrm{E}: \mathrm{M} \\
\mathrm{C}: \mathrm{M} \\
\text { Race NI }\end{array}$ & $\begin{array}{l}\text { No smoking; without } \\
\text { diabetes; severe } \\
\text { obesity; severe hy- } \\
\text { pertension; history of } \\
\text { falls, and those with } \\
\text { neurological, mental } \\
\text { or cognitive disor- } \\
\text { ders, and orthopedic, } \\
\text { pulmonary or cardiac } \\
\text { problems that could } \\
\text { restrict their activity/ } \\
\text { None of the partici- } \\
\text { pants was using any } \\
\text { medications that would } \\
\text { alter } \\
\text { vascular function }\end{array}$ & MT & $\begin{array}{l}\text { Aerobic } \\
\text { and circuit } \\
\text { strength } \\
\text { training for } \\
\text { lower limbs } \\
\text { and upper } \\
\text { limbs }\end{array}$ & 3 & 60 & 32 & 30STS & NS & 6 \\
\hline 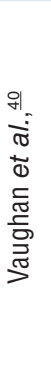 & $\begin{array}{l}\text { E: } 73.1 \pm \\
3.6 \\
\text { C: } 69.5 \pm \\
3.6\end{array}$ & $\begin{array}{l}\mathrm{E}: \mathrm{F} \\
\mathrm{C}: \mathrm{F} \\
\text { Race NI }\end{array}$ & $\begin{array}{l}\text { Health, inability to } \\
\text { obtain written clear- } \\
\text { ance from a general } \\
\text { practitioner; without a } \\
\text { diagnosis of dementia } \\
\text { or Parkinson's disease; } \\
\text { ability to walk } 20 \text { me- } \\
\text { ters unaided and head } \\
\text { injury within the } \\
\text { previous } 12 \text { months/ } \\
\text { Medication: NI }\end{array}$ & MT & $\begin{array}{l}\text { Strength } \\
\text { training, } \\
\text { coordination } \\
\text { and aerobic } \\
\text { and balance } \\
\text { training }\end{array}$ & 2 & 60 & 16 & TUG & $\begin{array}{l}+ \\
p<0.001\end{array}$ & 10 \\
\hline
\end{tabular}

Continue... 


\begin{tabular}{|c|c|c|c|c|c|c|c|c|c|c|c|}
\hline \multirow[b]{2}{*}{ 咅 } & \multicolumn{3}{|l|}{ Subjects } & \multicolumn{7}{|l|}{ Training } & \multirow[b]{2}{*}{$\begin{array}{l}\text { Pe- } \\
\text { Dro }\end{array}$} \\
\hline & Age & $\begin{array}{l}\text { Gender/ } \\
\text { Race }\end{array}$ & $\begin{array}{l}\text { Health condition/ } \\
\text { Medication }\end{array}$ & $\begin{array}{l}\text { Type of } \\
\text { training }\end{array}$ & $\begin{array}{l}\text { Performed } \\
\text { activities }\end{array}$ & $\begin{array}{l}\text { Weekly } \\
\text { frequency } \\
\text { (week) }\end{array}$ & $\begin{array}{l}\text { Session } \\
\text { duration } \\
\text { (min) }\end{array}$ & $\begin{array}{l}\text { Total } \\
\text { duration } \\
\text { (week) }\end{array}$ & Tests & Effect & \\
\hline 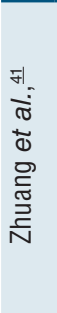 & $\begin{array}{l}\text { E: } 70.8 \pm \\
4.1 \\
\text { C: } 70.2 \pm \\
4.5\end{array}$ & $\begin{array}{l}\text { E: F/M } \\
\text { C: F/M } \\
\text { Race NI }\end{array}$ & $\begin{array}{l}\text { Health, able to walk } \\
\text { without a cane or other } \\
\text { assistive device, with- } \\
\text { out medical conditions } \\
\text { and musculoskeletal } \\
\text { problems } \\
\text { limiting safe participa- } \\
\text { tion in an exercise pro- } \\
\text { gram/Medication: NI }\end{array}$ & MT & $\begin{array}{l}\text { ST for lower } \\
\text { limbs and } \\
\text { upper limbs, } \\
\text { balance and } \\
\text { Tai chi chuan } \\
\text { exercise }\end{array}$ & 3 & 60 & 12 & $\begin{array}{l}\text { TUG; } \\
\text { 30STS }\end{array}$ & $\begin{array}{l}\text { TUG: }+ \\
\text { p<0.001 } \\
\text { 30STS: } \\
\text { NS }\end{array}$ & 8 \\
\hline 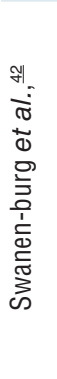 & $\begin{array}{l}\text { E: } 71.8 \pm \\
5.4 \mathrm{C}: \\
70.7 \pm 8.1\end{array}$ & $\begin{array}{l}\mathrm{E}: \mathrm{F} \\
\mathrm{C}: \mathrm{F} \\
\text { Race NI }\end{array}$ & $\begin{array}{l}\text { Older adult with osteo- } \\
\text { penia or osteoporosis, } \\
\text { patients without any } \\
\text { severe peripheral or } \\
\text { central neurological } \\
\text { disease known to } \\
\text { influence gait, balance } \\
\text { or muscle strength/ } \\
\text { Without medical } \\
\text { contraindications } \\
\text { for exercise }\end{array}$ & MT & $\begin{array}{l}\text { ST for lower } \\
\text { limbs and } \\
\text { upper limbs, } \\
\text { coordina- } \\
\text { tion, aerobic } \\
\text { and balance } \\
\text { training }\end{array}$ & 2 & 60 & 12 & EBB & $\begin{array}{l}+ \\
p=0.008\end{array}$ & 9 \\
\hline 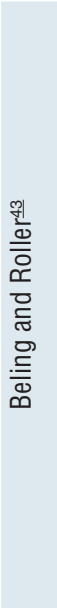 & $\begin{array}{l}\mathrm{E}: 79.1 \pm \\
6.5 \\
\text { C: } 81 \pm 5\end{array}$ & $\begin{array}{l}\mathrm{E}: \mathrm{F} / \mathrm{M} \\
\mathrm{C}: \mathrm{F} / \mathrm{M} \\
\text { Race NI }\end{array}$ & $\begin{array}{l}\text { No history of cardiac } \\
\text { conditions, muscu- } \\
\text { loskeletal, and/or } \\
\text { neurologic limitations } \\
\text { that could account for } \\
\text { possible imbalance } \\
\text { and falls such as cer- } \\
\text { ebrovascular accident, } \\
\text { spinal cord injury, } \\
\text { Parkinson disease, } \\
\text { transient ischemic at- } \\
\text { tacks, lower-extremity } \\
\text { joint replacements/ } \\
\text { fusions/ amputations } \\
\text { (could use a cane or } \\
\text { walker), or fracture } \\
\text { within past year/Medi- } \\
\text { cation NI }\end{array}$ & MT & $\begin{array}{l}\text { Balance } \\
\text { training, } \\
\text { circuits and } \\
\text { functional } \\
\text { stations }\end{array}$ & 3 & 60 & 12 & $\begin{array}{l}\text { TUG; } \\
\text { EBB }\end{array}$ & $\begin{array}{l}\text { TUG: NS } \\
\text { EEB:+ } \\
p \leq 0.05\end{array}$ & 6 \\
\hline 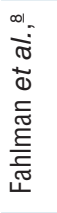 & $\begin{array}{l}\text { E: } 69.1 \pm \\
3.1 \\
\text { C: } 67.4 \pm \\
2.7\end{array}$ & $\begin{array}{l}\mathrm{E}: \mathrm{F} / \mathrm{M} \\
\mathrm{C}: \mathrm{F} / \mathrm{M} \\
\text { Race NI }\end{array}$ & $\begin{array}{l}\text { Health, without un- } \\
\text { controlled angina, any } \\
\text { health problem that } \\
\text { prohibited moderate } \\
\text { resistance or aerobic } \\
\text { training/Medication: } \mathrm{NI}\end{array}$ & $\begin{array}{l}\text { ST e } \\
\text { MT }\end{array}$ & $\begin{array}{l}\text { SG: ST } \\
\text { MG: aerobic } \\
\text { and ST with } \\
\text { elastic bands }\end{array}$ & 3 & $\mathrm{NI}$ & 16 & 30STS & $+p<0.05$ & 5 \\
\hline 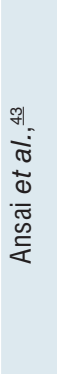 & $\begin{array}{l}\mathrm{E}: 82.2 \pm \\
2.8 \\
\mathrm{C}: 82.6 \pm \\
2.6\end{array}$ & $\begin{array}{l}\mathrm{E}: \mathrm{F} / \mathrm{M} \\
\mathrm{C}: \mathrm{F} / \mathrm{M} \\
\text { Race NI }\end{array}$ & $\begin{array}{l}\text { Health, without injury } \\
\text { listed in the absolute } \\
\text { contraindications of } \\
\text { the Physical Activ- } \\
\text { ity, without relative } \\
\text { cognition, neurological } \\
\text { or skeletal muscle } \\
\text { contraindications / } \\
\text { Medication: NI }\end{array}$ & $\begin{array}{l}\text { ST e } \\
\text { MT }\end{array}$ & $\begin{array}{l}\text { SG: Strength } \\
\text { training for } \\
\text { lower limbs, } \\
\text { upper limbs } \\
\text { and core; } \\
\text { MG: warming } \\
\text { up, aerobic, } \\
\text { strength } \\
\text { and balance } \\
\text { training and } \\
\text { stretching }\end{array}$ & 3 & 60 & 16 & 5STS & $\begin{array}{l}+ \\
p<0.001\end{array}$ & 8 \\
\hline
\end{tabular}

Subtitle: QA: Quality evaluation; ST: Strength training; MT: Multicomponent training; SG: Strength Group; MG: Multicomponent Group; E: Experimental Group; C: Control Group; M: Male; F: Female; NI: Not informed; 30STS: Sit to stand 30 seconds; 5 STS: Sit to stand 5 repetitions; TUG: Timed-up-and-go; BBE: Berg Balance Escale; +: positive results; NS: Not significant. 